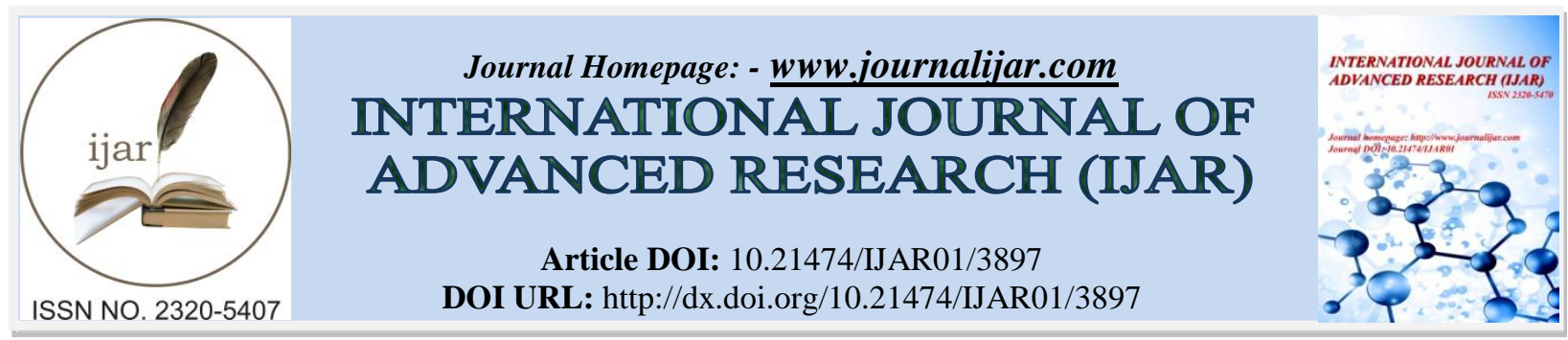

RESEARCH ARTICLE

\title{
MEDİA, MIGRATION AND CRIME: SYRIAN REFUGIES.
}

Meryem Bulut.

Ankara University, Faculty of Languages, History and Geography, Department of Anthropology, Ankara, Turkey.

\section{Manuscript Info}

Manuscript History

Received: 12 February 2017

Final Accepted: 15 March 2017

Published: April 2017

Key words:-

Syrian Refugees, Migration, Crime, Media

\begin{abstract}
The relations between migration and crime have long been discussed, and they are complex. The issue, which is usually put as " does migration increase the rate of crime?" and which has the risk of being one-sided and biased, has been analysed in recent years in Turkey also. The concepts of immigrant and crime rate are considered to be directly connected with the way that people perceive immigrants and mostly with the way that they label immigrants. Such labelling or rather stigmatizing, was triggered by the case of 'fear of Crime' as stated in the Western countries. The fear of crime is triggered, and the stereotype that immigrants are potential criminals is produced. Mass media also shapes the migration-criminal association. This study discusses that the migration-crime association is a set of learnt concepts rather than objective reality, and how the Syrian immigrants are considered in mass media. In this study, a media and comment scanning process has been conducted in terms of news and comments on the issues of Syrian asylum seekers and crime on the web sites of the general (national) newspapers.
\end{abstract}

Copy Right, IJAR, 2017,. All rights reserved.

\section{Introduction:-}

The migration legislation introduced after the foundation of the Turkish Republic in 1923 was adopted in order to consolidate the security of the nation state. Therefore, the legislation on the acceptance of immigrants favoured the immigrants of Turkish origin. Turkey applies "geographical limitation" in terms of acceptance of immigrants. This implementation might have been considered as a solution for the migration flow expected from Middle Eastern countries due to the turbulent situation in these countries. The pattern of migration into Turkey began to change due to the economic and political transformations in the neighbouring countries after 1980's. While Turkish and/or Muslim immigrants were coming to Turkey during the previous periods, after 1980's foreigners also started to migrate. During that period, Turkey turned to be a destination country of immigration (İçduygu, 2012). In general, immigrants are those that are forced politically or due to wars to resettle within their own country and are in need of all aids required by the refugee status. Their inclusion into another category as refugee is due to the risk of persecution or death within the national borders of the country they reside in. In other words, they are forced to live in an isolated region, camp in another part of the country after fleeing their own area of residence due to war, ethnical/religious conflicts or discriminatory policies and treatment in a manner that excludes them from all administrative processes and deprives them of state protection as well as public services. In the international literature, the persons that are displaced from their residence regions in the country are called "Internally Displaced People" (Baklacioğlu, 2010).

Corresponding Author:- Meryem Bulut. 
Currently one of the most important problems of Turkey is Syrians. Turkey hosts too many Syrians (İçduygu, 2015). In Syria, a multidimensional and multiparty war with very destructive aspects continues. Turkey became the world's largest refugee host country in 2014. As of 30 June, the Directorate General of Migration Management (DGMM) announced that 2,733,044 Syrians were registered in Turkey, out of whom 256,300 were hosted in refugee camps, and $2,476,744$ were residing in host communities ${ }^{1}$.

Since the war began in 2011, there have been over 4,000 attacks on schools. "In Syria children are risking death to go to school. In the past two weeks, nine school-children, aged as young as five, lost their lives in two separate attacks on or near schools," says Hanaa Singer UNICEF's Representative in Syria. "School should not be a death trap. It should a place where children are protected and able to learn, grow, and develop their skills." 2 Turkey opened the doors to Syrian refugees including those without any identification card. Syrian passport holders may enter Turkey without visa and may obtain residence permit in any provinces of Turkey they want except the provinces of Hatay and Şırnak. At the Military Checkpoints, the access of Syrians to Turkey has been limited to those that require medical treatment. Due to the open borders policy, Turkey is one of the first addresses of the Syrian asylum seekers. There is no reliable information about the number of Syrian refugees. ${ }^{3}$ However, it is estimated that the total number has reached to 2 million from 1 million 385 thousand due to falling of Syria under the ISIS threat ${ }^{4}$.

Turkey's open borders policy, the services provided to Syrian asylum seekers at temporary residence centres and the financial burden assumed by Turkey are praised by international society and underlined by the representatives of international humanitarian assistance organisations and journalists. In this regard, the most notable news is "How to build a perfect refugee camp" that is published at USA's reputable newspaper New York Times ${ }^{5}$. Political and social silence in Turkey about the immigration flow and inexistence of any social panic has surprised the USA ${ }^{6}$. Historical, cultural, social and economic reasons of that situation can be a research topic. There is no discomfort due to people coming from Syria who are expected to turn back to their country at the beginning. However, as the number of Syrian refuges that are described as guests increased as well as their residence duration. Nevertheless, Syrian crisis, together with a network of conflicts at the international, regional and local levels has also led to criticism about Syrians from some parts of population living in Turkey, although they mind the humanitarian aspects of the issue.

Prolongation of the civil war and increase in the number of refugees and thus increase in the rent prices, decrease in the wages of the workers employed in the agriculture, industry, construction and service sectors due to illegal working of asylum seekers have led to unrest in the society. Hesitation about renting houses to Syrians has increased recently. The cases such as non-payment of rents and causing problems not to pay, or renting a house as a family but increasing the number residents up to 10-20 people are frequently encountered. Everywhere in the world, among the main issues that led to disturbance of people and even to xenophobia are those are "risk of losing job" or "decrease in income due to increased labour supply and competitiveness". This situation can clearly be observed in the region (Erdoğan, 2014). Extraordinary concentration of population especially in the border cities has significant impacts on the cultural, social and economic fabric of the cities and results in increased level of tension and discontent among the local people (Erdoğan, 2014).

It is very widespread that Syrians have been associated with the crimes such as theft, prostitution, extortion and damage to public property. However, studies indicate that the delinquency rate of Syrians is less than that of local public. Local people frequently complaint about the fact that "with the Syrians coming to Turkey their peace has broken and while they left their doors unlocked during the night, now thieves, bullies are everywhere." Also it has

\footnotetext{
${ }^{1}$ unhcr_turkey_operational_update_jan-june_2016.pdf $1 / 9$

${ }^{2}$ UNICEF MENA web site. http://childrenofsyria.info/

${ }^{3}$ Syrian Refugees in Turkey, UNHCR Turkey.

http://www.unhcr.org.tr/?content=525

${ }^{4}$ Syria Disaster Report, AFAD - Prime Ministry, Disaster and Emergency Management Presidency, 7 November

2014. https://www.afad.gov.tr/TR/IcerikDetay1.aspx?ID=16\&IcerikID=747

${ }^{5}$ http://www.nytimes.com/2014/02/16/magazine/how-to-build-a-perfect-refugee-camp.html?_r=0

${ }^{6}$ Oxford University Centre of Migration, Policy and Society (COMPAS) researcher Frank Duvel, article dated January 2013, Report of Non-Governmental Organizations on Their Studies on Syrian Refugees in Turkey, Publications of Asylum and Immigration Research Centres, Ankara, 2013.
} 
been said that young Syrian women act as prostitutes. However it has been concluded that these claims are mostly rumours (Akdeniz, 2014).

A landlord was murdered by the Syrian tenant on 11 August 2014 in Gaziantep and following that event, an overcrowded group started assaulting on the Syrians that they saw on the streets. During these incidences which turned to be a social lynching, some of the Syrians attacked with stones, bats and knifes were wounded and their houses, offices and vehicles were damaged. Following the attacks, some of the Syrian women started to wear like the women living in Antep and even some of them fly Turkish flag on their houses. Some of the Syrians had to flee the quarter they lived either with force or due to urgency. ${ }^{7}$ The lynching cases against the Syrians reveal that the perception of local people about Syrians in that region has turned into hatred. As it is mentioned in the crime theories, this situation has initiated a process that embitters the xenophobia. It is possible to encounter in many countries such prejudice against Syrian immigrants as they commit crimes. For instance, a strong belief that the perpetrators of the explosion occurred in France had come to France as the number of immigrants coming from the Middle East grew. Actually, the criminal was a French or Belgian citizen (Kis-Benedek, K.(2016:455-464). Reactions against the immigrants is similar to those all over the world. In this regard, it is observed that during the crisis periods, the hatred discourse is easily blended with racism. In terms of relation between immigration and crime, it is frequently mentioned at the social media and mainstream media news in Turkey that Syrian immigrants have a tendency towards crime and lead to increase in the crime rate. The comments on social media environment clearly indicate how the discourse of hate has been triggered. When the discourse of hate has been considered together with the threatening concept of crime, it can be more intense. This indicates how the perception for others turns into hatred. This study touches on the issue that how the Syrian asylum seekers have been positioned in the media.

\section{Data Collection and Evaluation:-}

In this study, a media and comment scanning process has been conducted in terms of news and comments on the issues of Syrian asylum seekers and crime on the web sites of the general (national) newspapers. The scope of the research is limited to the media news on the national newspapers in Turkey on the Syrian asylum seekers. The newspapers were selected according to their ideological stance such as being liberal, conservative and leftist.

\section{Syrian Asylum Seekers In Media:-}

It is not possible to state that the newspapers select, except one, have taken Syrian asylum seekers into consideration with all dimensions of the issue. It is observed that the features of all nine newspapers analysed are related with the ideological structure and position of the newspaper vis-à-vis the government party. The news on Syrian asylum seekers in the liberal newspapers is mostly like magazine news. For example, in the news about a quarrel the "Syrian family" involved was described as walking topless at home while the curtains are open and listening to music loudly. It was also mentioned that after the police intervention to the quarrel, the residents of the quarter fly Turkish flag on their windows and reacted against Syrians. It has been observed that there is no in-depth analysis. On the other hand, it is possible to explain the different news of liberal newspapers about the Syrians in terms of their opposition to the government party. Another liberal daily newspaper that has the impression of opposing to the government party claimed that "Turkey is in the route to create a new internal enemy for itself". The conflicts with the Syrian asylum seekers were published with these titles. Could this attack be avoided provided that the curtains were not open as claimed by the newspaper? It is observed that there is an effort to construct a link between crime and immigrants. In addition to the notion of immigrants that are unable to adapt to the regions they have migrated and are in search of "marginal" solutions due to their economic troubles; another ground pointing to a symbolic threat is that the immigrants shall create a cultural threat for the "local people" of the destination countries (Corliss, Curtis \& Fitzgerald, 2012). Thus an impression that the Syrian asylum seekers cannot adapt to another country is also created. Opening of the window curtains or being naked can signify that they cannot adapt. However, flying Turkish flags indicates that Syrian asylum seekers have been perceived as a cultural threat. The immigrants carry the risk of damaging the resources and identity of the destination country.

The quality of news covered by the conservative newspapers depends on their political proximity to the government party. The newspapers close to the government party made positive news about the Syrian asylum seekers. For example, the news about issuing biometrical identity cards for Syrians or issuing temporary license plates for the

${ }^{7}$ Gaziantep’teSuriyelilereYönelikSaldırılarveToplumsalNefretinSebeplerininAnalizineDairRapor, Kasım 2014. http://gaziantep.mazlumder.org/fotograf/yayinresimleri/dokuman/Suriyeliler-1.pdf 
vehicles of Syrians took place on these newspapers. It was also mentioned that Syrians were pleased with Turkish license plates since they would be able to travel easily. Providing education services for Syrian students, awarding long-term scholarships for the students, issuing Turkish license plates are relatively positive news. It is possible to state that, the newspapers of conservative tendency but not close to the government party have pessimistic discourses about the Syrian asylum seekers. Issuing identity cards is considered as a control mechanism of asylum seekers and it is also a tool of accessing them easily. On the other hand, expressions of Syrians that they will travel easily with Turkish license plates can be interpreted as they are avoiding to be seen as Syrians.

It is possible to mention that the leftist newspapers have multi-dimensional news about Syrian asylum seekers. These newspapers provide and reflect an in-depth analysis of the troubles of asylum seekers, the treatments they are exposed to. These news include issues ranging from the employers attitudes to the cases of deportation which are the incidents not covered in other newspapers. It has already been revealed that in the liberal newspapers, the problem is the attitudes of the Syrian asylum seekers and all disputes have arisen from their attitudes. It has also been mentioned that most of the conflicts have resulted in the evacuation of Syrians from their residence quarters and houses. In the leftist newspapers (opposing the government) the news about the Syrians also include the news on protesting of attitudes that the Syrians are exposed to. By giving place to the research about the conflicts, the leftist newspapers address the economic reasons behind the conflicts. These newspapers emphasise that they are seen as cheap labour, and the fact such as dramatic increase in the housing prices, decrease in the wages, desperate labourers facing with the risk of unemployment and thus provoked by anger turn into racist discourse.

Despite all these reactions, it is observed that Syrians have to work at lower wages and longer working times than the Turkish workers and thus vulnerable to exploitation. These newspapers also give place to the impact of sectarian differences on the attitudes of people against the Syrian refugees. The people holding the Nusayri identity in the Hatay province of Turkey might have clearly positioned themselves as pro-Syrian administration vis-à-vis the refugees and might have had discomfort with the Sunni refugees. It is possible to suggest that the leftist newspapers provide detailed news about the conditions of the Syrian asylum seekers.

According the results of the analyses made by Göktuna, Yaylacı and Karakuş in relation to the perceptions of Syrian refugees which also reflected into newspapers (Hürriyet, Yeni Şafak and Cumhuriyet), newspapers' attitudes towards the government in power influence their manner of writing the news (Göktuna Yaylac1 ve Karakuş,2015:238-250). The finding obtained in this study also confirms the above mentioned statement.

In the news on the newspapers, there is an emphasis on the immigrants who are perpetrator of the crimes rather than the immigrants who are the victims of the crimes. The perception management for considering the immigrants with committing crime ignores the exposure of immigrants to double victimization; in other words, the fear of crime turns into the fear of committing crime without questioning what the immigrants are experiencing (Collins, 2007). Therefore it is necessary to see Syrians not only as perpetuators but also as the victims.

\section{Conclusion:-}

The study has evaluated the positioning of the Syrian asylum seekers in the media. It has been identified that the characteristics of the news on the newspapers are related with the ideological structure of the newspaper and its position vis-à-vis the government party. It has been observed that there is no in-depth analysis in the newspapers. It is not possible to state in general that they attach importance to the Syrians. The perception that immigrants are in search due to the adaptation problems in their residence region or their economic troubles has associated the immigrants with crime.

We cannot say that most of the newspapers analysed exhibit the problems Syrian refugees have experienced. The quality of the news stories included in newspapers differ according to the ideology of the newspapers and to whether or not they are close the ruling party. The news is rather tabloidised in liberal newspapers. It is clear that there are no in-depth comments. On the other hand, when newspapers which are classified as liberal write about these Syrian refugees differently, they can be labelled as opposite to the party in power.

Newspapers signal in their news stories that Syrian refugees go to a country but cannot adjust to the country. Accordingly, it is pointed out that refugees will be more comfortable if they hide their differences. 
The great migration flow from Syria has led to new problems in Turkey. The reactions in most of the migration destination countries have similarities with the reactions in Turkey. In this regard, it can easily be observed that during the economic crisis, the discourse of hate has been blended with racism. It can also be observed in the newspapers that Syrians are considered as cheap labour, and the fact such as dramatic increase in the housing prices, decrease in the wages, desperate labourers facing with the risk of unemployment and thus provoked by anger trigger racist discourse. There is an emphasis on the immigrants who are perpetrator of the crimes rather than the immigrants who are the victims of the crimes. The news revealing that the tensions caused by the use of cheap workforce turns into racist discourse are available only in newspapers using leftist discourse. When the media news are evaluated, it is necessary to consider the Syrians not only as perpetuators but also as the victims. The relationship between migration and crime has long been discussed for more than a century in the academic researches and social policy implementations (Martinez \& Lee, 2000, Ousey\&Kubrin, 2009). The relationship between migration and crime continues to take place among today's mostly discussed issues. However, it is difficult to say that a satisfactory answer has been provided about the type of correlation existing between these two phenomenons. Migration and crime are far from consideration as two constant phenomenons; both include complex and overlapping processes and there are many unanswered questions on the correlation between the two. The relationship between migration and crime is shaped by the definition of the network of relations that interact positively or negatively with each other. The claim that the crime rate is higher in the regions where there are higher number of immigrants that settled through internal migration and immigration is frequently proposed. The issue of to what extend the crime rate and migration is related has been studied especially in the Western countries that have been accepting high numbers of immigrants since 1900's. This topic that is unilaterally problematized in a minimalist way asking the question of "whether migration increases the crime rate?" continues to be discussed today as well; and it seems that it will continue so for a long time. There is no single and simple answer to the question of "how does migration affect crime?" but different responses to this question reveal different aspects of the issue.

Besides, the biggest problem arising between Syrian immigrants and Turkey the hosting country is the rising tension according to Yazgan, Utku \& Sirkeci. Activities should be done to reduce the tension between the hosting country and the immigrants (Yazgan, Utku \& Sirkeci, 2015).

On examining the effects of the migration wave reaching along with the crisis in Syria on the country via the mass media, it is found that differing evaluations have been made in relation to immigrants. In this context, while government policies as well as their consequences are directly mentioned in some media organisations, Syrian immigrants' rights and lives are considered critically.

\section{Bibliography:-}

1. Akdeniz, E. (2014) Suriye Savaşının Gölgesinde Mülteci İşçiler Evrensel Kültür Kitaplığı, İstanbul

2. Afet ve Acil Durum Yönetimi Başkanlığı, Suriyeli Misafirlerimiz Kardeş Topraklarında Haziran 2014.https://www.afad.gov.tr/Dokuman/TR/98-2014061912629-suriyeli-misafirlerimiz.pdf

3. Baklacıoğlu, N. Ö.(2010), Dış Politika ve Göç Yugoslavya'dan Türkiye’ye Göçlerde Arnavutlar (1920-1990), Derin Yayınları, İstanbul

4. Corliss, C. L., Curtis, A. \& Fitzgerald, K. J. (2012). Anxious Publics: Worries About Crime and Immigration. Comparative Political Studies, 45, 477-506.

5. Collins, J. (2007). Immigrants as Victims of Crime and Criminal Justice Discourse in Australia. International Review of Victimology. 14: 57-79.

6. Duvel, F.(2013), Oxford Üniversitesi," Göç, Politika ve Toplum Merkezi (COMPAS) Sivil Toplum Örgütlerinin Türkiye'deki Suriyeli Mülteciler İçin Yaptıkları Çalışmalar İle İlgili Rapor, İltica ve Göç Araştırmaları Merkezi Yayınları, Ankara

7. Erdoğan, M. M. (2014), Türkiye'deki Suriyeliler: Toplumsal Kabul ve Uyum, Hacettepe Üniversitesi, Göç ve Siyaset Araştırma Merkezi, Hugo

8. Gaziantep’te Suriyelilere Yönelik Saldırılar ve Toplumsal Nefretin Sebeplerinin Analizine Dair Rapor Kasım 2014. http://gaziantep.mazlumder.org/fotograf/yayinresimleri/dokuman/Suriyeliler-

9. Göktuna, Yaylacı ve Karakuş (2015), Perceptions and newspaper coverage of Syrian refugees in Turkey, Migration Letters,ISSN:1741-8984, e-ISSN:1744-8992, 238-250

10. İçduygu, A. Biehl, K. ( 2012), Kentler ve Göç (Türkiye, İtalya, İspanya), “Türkiye’ye Yönelik Göçün Değişen Yörüngesi” İstanbul Bilgi Üniversitesi Yayınları, İstanbul

11. İçduygu, A. (2015), Syrian Refugees in Turkey The Long Road Ahead, Transatlantic Council on Migration, A Project of the Migration Policy Institute 
12. Kirişci, K. Misafirliğin Ötesine Geçerken: Türkiye'nin "Suriyeli Mülteciler” Sınavı, (Çev: S. Karaca), Brookings Enstitüsü, Uluslarası Stratejik Araştırmalar Kurumu(USAK)

13. Lee, T. M., Martinez, R. (2000). On Immigration and Crime. Criminal Justice National Criminal Justice Reference Service, https://www.ncjrs.gov/criminal_justice2000/vol_1/02j.pdf

14. Martinez \& Lee (2000), On Immigration and Crime, National Criminal Justice Reference System,http://www.nytimes.com/2014/02/16/magazine/how-to-build-a-perfect-refugee- camp.html?_r=0

15. Ousey\&Kubrin (2009), Exploring the Connection between Immigration and Violent Crime Rates in U.S. Cities, Editor(s): William F. Mcdonald ISBN: 978-1-84855-438-2 e-ISBN: 978-1-84855-439-9, 1980-2000, http://dx.doi.org/10.1108/S1521-6136(2009)0000013005

16. Refugee Studies Center, Ensuring Quality Education for Young Refugees from Syria (12-25 years) Eylül 2014.http://www.rsc.ox.ac.uk/publications/ensuring-quality-education-for-young-refugees-from-syria-appingexercise-on-quality-education-for-young-refugees-from-syria-12-25-years/files/publications/other/rr-syriayouth-education-2014.pdf

17. Suriye Afet Raporu, AFAD - Başbakanlık Afet ve Acil Durum Yönetimi Başkanlığı, 7 Kasım 2014. https://www.afad.gov.tr/TR/IcerikDetay1.aspx?ID=16\&IcerikID=747

18. Türkiye'deki Suriyeli Mülteciler, UNHCR Türkiye.http://www.unhcr.org.tr/?content=525

19. Uluslararası Af Örgütü, Hayatta Kalma Mücadelesi: Türkiye'deki Suriye'den Gelen Mülteciler raporu, 2014. http://amnesty.org.tr/uploads/Docs/hayatta-kalma-mucadelesi-turkiye'deki-suriye'den-gelen-multeciler720.pdf

20. UNICEF, Kuşatma Altında - Suriye'de Üç Yıldır Süren Çatışmaların Çocuklar Üzerindeki Yıkıcı Etkileri Mart 2014.http://www.unicef.org/publications/files/Under_Siege_March_2014.pdf

21. USAK \& Brookings, Misafirliğin Ötesine Geçerken: Türkiye'nin Suriyeli Mülteciler Sinavı Raporu, Haziran2014.

http://www.usak.org.tr/images_upload/files/misafirligin_otesine_gecerken_turkiyenin_suriyeli_multeciler_sina vi-Kemal-Kiri\%C5\%9Fci\%20(1).pdf

22. USAK-Brookings, Suriyeli Mülteciler ve Türkiye: Sonu Gelmeyen Misafirlik Raporu, Kasım 2013. http://usak.org.tr/images_upload/files/Suriyeli_M\%C3\%BClteciler_ve\%20T\%C3\%BCrkiye_Sonu\%20Gelmeye n_Misafirlik_Dincer_Karaca_Ozmenek.pdf

23. USAK-Brookings, Sınırlar Arasında Yaşam Savaşı Suriyeli Mülteciler Alan Çalışması, Mayıs, 2013.http://usak.org.tr/images_upload/files/m\%C3\%BClteciler\%20rapor\%20nete.pdf

24. Yazgan, Utku \& Sirkeci(2015), Syrian Crisis and Migration, Migration Letters, ISSN:1741-8984, eISSN:1744-8992, Vol 12, No 3:181-192 